\title{
Redes sociais em comunidades de baixa renda: os efeitos diferenciais dos laços fracos e dos laços fortes*
}

\author{
Antônio Augusto Pereira Prates**
}

SumÁrio: 1. Introdução; 2. Proposição teórica; 3. Teste de hipóteses; 4. Conclusão.

Summary: 1. Introduction; 2. Theoretical proposal; 3. Hypotheses test; 4. Conclusion.

Palavras-chave: capital social; ação coletiva; laços fracos; eficácia coletiva; clientelismo; desorganização social; violência.

KEY words: social capital; collective action; weak ties; collective efficacy; patronclients relationships; social disorganization; violence.

Neste artigo demonstramos, a partir de uma replicação qualitativa de um estudo quantitativo, que os sistemas fechados de interação - aqui denominados capital social - e os abertos — laços fracos — são fenômenos de natureza distinta e, consequentemente, desempenham funções distintas na determinação da capacidade de articulação coletiva de indivíduos e no grau de eficácia de ações coletivas. A hipótese principal do artigo é que, enquanto capital social tem a ver com maior capacidade dos membros da comunidade para articular mobilização social, os laços fracos dizem respeito à capacidade de a comunidade conseguir benefícios, como saneamento básico, segurança pública, transporte coletivo, saúde e lazer - aqui denominada eficácia coletiva. A metodologia adotada baseia-se na replicação qualitativa de um survey, com três estudos de caso em comunidades periféricas da Região Metropolitana de Belo Horizonte, sobre a importância dos laços fracos para a ação eficaz da comunidade diante do poder público.

\footnotetext{
* Artigo recebido em jan. e aceito em jul. 2009.

** Professor associado do Departamento de Sociologia e Antropologia da Faculdade de Filosofia e Ciências Humanas da Universidade Federal de Minas Gerais (Fafich/UFMG). Doutor em sociologia pela UFMG, mestre em sociologia pela State University of New York em Stony Brook. Endereço: Rua Artur Itabirano, 360, ap. 41 - CEP 31275-020, Belo Horizonte, MG, Brasil. E-mail: aaprates@oi.com.br.
} 


\section{Social networks in low-income communities: the differential effects of weak and strong ties}

This article demonstrates, through a qualitative replication of a quantitative research - a survey - that the concepts of closed interaction systems — social capital - and open ones - weak ties - refer to different kinds of social phenomena and, therefore, have independent roles in determining the individuals' capability of collective articulation as well as the effectiveness of the collective actions. The main hypothesis is that while social capital has to do with the people's ability to articulate social mobilization, weak ties have to do with the community's capability to obtain services such as sanitation, public safety, transportation, health care and leisure facilities - here called collective effectiveness. The study comprised a qualitative replication of a survey, with three case studies of low-income communities in the Belo Horizonte metropolitan area.

\section{Introdução}

Este artigo discute as relações empíricas de duas dimensões estratégicas da ação coletiva: o capital social (laços fortes) e as conexões intergrupais ou interinstitucionais, os laços fracos. Embora, como veremos a seguir, a literatura corrente sobre capital social não faça uma distinção teórica ou analítica entre essas duas dimensões, sustentaremos neste artigo que elas são analiticamente independentes e que essa distinção é heuristicamente proveitosa para se compreender satisfatoriamente a questão da ação coletiva. ${ }^{1}$ As referências empíricas do artigo têm duas bases distintas de dados: uma primeira, de natureza quantitativa, produzida por um survey, e a segunda, de natureza qualitativa, produzida por três estudos de caso, ambas as bases de dados referentes à Região Metropolitana de Belo Horizonte (RMBH) no período de 2006 a 2008.

\footnotetext{
${ }^{1}$ A primeira parte deste artigo retoma a discussão sobre a relação entre capital social e laços fracos elaborada por Prates, Carvalhaes e Silva (2008) com base na primeira etapa do Programa de Pesquisa sobre Capital Social e Ação Coletiva, sob minha coordenação, em realização no Centro de Pesquisa Quantitativa (Cepeqs) da Fafich/UFMG, como módulo do projeto-mãe Pesquisa da Região Metropolitana de Belo Horizonte, coordenado pela professora Neuma Aguiar, com apoio financeiro em diferentes etapas da Fundação Ford, Fundação Tinker, Fundação de Amparo à Pesquisa do Estado de Minas Gerais (Fapemig) e Conselho Nacional de Desenvolvimento Científico e Tecnológico (CNPq). A segunda parte do artigo baseia-se no projeto no SHA-808-06 financiado pela Fapemig e coordenado por mim. Esta pesquisa é de natureza qualitativa e cobriu três comunidades carentes no município de Belo Horizonte. Ela contou com a participação dos seguintes bolsistas de Iniciação Científica da Fapemig: Raquel Guilherme de Lima, Túlio Silva, Ian Cordeiro Prates e Matheus Faleiro, o qual trabalhou neste projeto voluntariamente. Agradeço a todos pelo grande empenho durante a pesquisa de campo.
} 
Esses estudos são parte do nosso Programa de Pesquisa sobre Capital Social e Redes Sociais: no primeiro estudo tentamos demonstrar a independência estatística das duas dimensões-chave da nossa discussão: capital social e redes sociais e seus efeitos diferenciais sobre a eficácia coletiva da população pobre de Belo Horizonte. No segundo estudo, tentamos perceber se, do ponto de vista do significado da ação dos moradores das comunidades carentes, essa distinção analítica continuava a fazer sentido para explicarmos o diferencial de eficácia coletiva das comunidades pobres ao buscarem benefícios coletivos e públicos. Enquanto as unidades de análise do primeiro estudo foram os indivíduos, no segundo desenho da investigação as unidades de análise foram as comunidades.

\section{Proposição teórica}

Embora os estudos empíricos em que este artigo se baseia se voltassem para a questão sobre capital social, logo no início da abordagem do tema fomos levados a buscar na teoria de redes sociais as qualificações teóricas essenciais do conceito de capital social. A primeira questão que deparamos ao tentar utilizar o conceito de capital social foi a da indefinição, ou melhor, da multiplicidade de significados distintos atribuídos a um único termo. Isso nos fez lembrar a clássica crítica de Merton (1949) ao uso do termo "funcionalismo" na sociologia: "uma só palavra, conceitos diferentes" e "um só conceito, palavras diferentes" (Merton, 1949:30 e 33). ${ }^{2}$ No caso do conceito de capital social podemos aplicar in totum à crítica de Merton.

Se não, vejamos, de acordo com Coleman (1990) foi Loury (1977) que primeiro introduziu o termo na economia para designar os recursos inerentes ao seio da família que dotam seus filhos com maior ou menor capacidade cognitiva para o desenvolvimento do seu capital humano. Já Bourdieu e Coleman conceituam capital social de forma bem distinta de Loury, e, também, entre si. Para Bourdieu (1986) o capital social é um tipo de capital que qualifica a posição relativa das pessoas na estrutura de classe além do capital econômico. Mas é importante frisar que o capital social definido por Bourdieu é, como outros tipos de capital, referente em "última instância" à capacidade de indiví-

\footnotetext{
${ }^{2}$ Merton referia-se ao fato de que na literatura sociológica o termo "função" era utilizado tanto para designar fenômenos distintos, como, por exemplo, "ocupação", "cargo político", quanto para ser designada por "palavras" diferentes, tais como "utilidade, propósito, motivo, consequências ou finalidade". Veja, nesta linha, o inventário de conceitos de capital social apresentados por Woolcock (1998).
} 
duos e grupos - frações de classe - adquirirem capital econômico. Embora o conceito de Bourdieu refira-se a redes sociais, estas disporão ou não de capital social dependendo da posição relativa na estrutura de classe das pessoas que as compõem. Já, para Coleman (1990) o capital social é uma propriedade inerente dos grupos, independentemente da sua posição social. O traço mais importante do conceito de Coleman não é o de rede social e sua posição estrutural na sociedade, como no caso de Bourdieu, e sim o de "fechamento" das relações dentro do grupo; ou seja, de coesão interna do grupo. Mas embora esses autores tenham sido pioneiros na criação e discussão teórica do conceito de capital social, dois outros autores foram fundamentais para a ampliação do debate tanto na esfera acadêmica quanto na da aplicabilidade do conceito para a formulação de políticas públicas. O primeiro deles foi Putnam (1996) no seu conhecido livro sobre o processo de mudança no sistema político italiano entre 1977 e 1989 mostrando que a democratização da política italiana estava diretamente relacionada a uma forte cultura cívica, típica da região norte do país, associada a uma ampla difusão de associativismo, no estilo mais puro de uma organização social tocquevilliana, conduzia um processo amplo de desenvolvimento econômico e de eficiência governamental. ${ }^{3}$ É esse fenômeno do associativismo cívico, encontrado no norte da Itália, que o autor denomina capital social. O segundo autor responsável pela difusão do conceito de capital social aplicado à discussão do sistema institucional das sociedades como condição da democracia foi Fukuyama $(2001,2002)$. Ele sustenta a tese de que a condição para o funcionamento de um sistema democrático é a existência de capital social visto como "normas ou valores partilhados que promovem cooperação social, presentes em relações sociais reais" (2002:27).

O problema com esses conceitos é que eles, com exceção do de Coleman, não agregam nada mais, em termos heurísticos, ao que outros conceitos, já de há muito disponíveis na literatura sociológica, ofereciam para o tratamento analítico desses fenômenos. Assim, o conceito de capital social de Bourdieu 4 não agrega nada ao conceito de poder social, entendido como a posição diferencial das pessoas em redes de influência na sociedade. A enorme literatura americana dos anos 1960 sobre "poder local", tanto na perspecti-

\footnotetext{
${ }^{3}$ Para uma resenha crítica dessa obra, ver Prates (1997).

4 "Social capital is the aggregate of the actual or potential resources which are linked to possession of a durable network of more or less institutionalized relationships of mutual acquaintance and recognition - or in other words, to membership in a group - which provides each of its members with the backing of the collectivity-owned capital, a "credential" which entitles them to credit, in the various senses of the word" (Bourdieu, 1986:248-249).
} 
va elitista quanto na pluralista, já havia mostrado os efeitos diferenciais do poder das pessoas relacionado à sua posição em redes sociais. ${ }^{5}$ Da mesma forma podemos sugerir que os conceitos de capital social de Putnam (1996) ${ }^{6}$ e de Fukuyama não agregam nada ao conceito culturalista de sistema normativo ou cultura política na linha do clássico estudo de Verba e Almond (1963) sobre cultura cívica. Já o conceito de Coleman (1990) distingue-se dos outros na medida em que se refere ao fenômeno específico dos recursos que emergem da sociabilidade dentro de um grupo ou comunidade. Coleman (1990:302, 315) enfatiza as dimensões de densidade socioestrutural e a de "fechamento (closure)" dentro do grupo das relações sociais que compõem o capital social,

unlike other forms of capital, social capital inheres in the structure of relations between persons and among persons (...) As an attribute of the social estruture in which a person is embedded, social capital is not the private property of any of the person who benefit from it.

De outra parte, o conceito de capital social tem sido, também, utilizado na literatura corrente como solução para todos os problemas de comunidades carentes ou sociedades em processo de desenvolvimento. De forma ingênua, essa abordagem generalizou-se como orientação geral de instituições multilaterais de fomento de desenvolvimento econômico, assumindo como inquestionável o fato de que a existência de capital social entre os pobres seria um fator que, automaticamente, impulsionaria a comunidade para fora da condição de pobreza. Essa abordagem transformou-se em um forte apelo ideológico justificando políticas públicas de intervenção social voltadas para a formação de atitudes e valores consistentes com o modelo ideal de uma comunidade ativa, cívica, e com enorme estoque de capital social (Sachs e Lages, 2001).

Esta pequena amostragem de um enorme volume de literatura sobre o conceito de capital social é suficiente para iniciarmos nossa discussão sobre capital social e redes sociais. Retomo aqui minha posição já discutida em artigo anterior, ${ }^{7}$ em que sustento o argumento de que a característica principal do fenômeno designado pelo termo capital social é o "fechamento" das relações sociais, ou seja, a sociabilidade intragrupo. O que aqui denominamos, para

\footnotetext{
${ }^{5}$ Veja para uma boa revisão dessa literatura Prates, Carvalhaes e Silva (2008).

${ }^{6}$ Para uma discussão crítica do conceito de capital social de Putnam, ver Prates (1997).

${ }^{7}$ Ver Prates, Carvalhaes e Silva (2008).
} 
utilizar a linguagem de quem primeiro chamou a atenção na literatura sociológica contemporânea para os efeitos diferenciais desses dois tipos de relação social (Granovetter, 1973), "laços fortes", e que os laços relacionando um grupo com outro, os "laços fracos" adéquam-se mais ao conceito de redes sociais. Enquanto os laços fortes dentro de um grupo facilitam a articulação da ação coletiva por minimizar os efeitos do "dilema do carona" (Olson, 1965), as relações intergrupos não apresentam essa propriedade por se caracterizarem por contatos superficiais, não envolventes emocional e psicologicamente. Por outro lado, esse tipo de conexão social permite porosidade cultural e ideológica para os grupos sociais. Nesse sentido estamos em direção contrária à de Lin (2000:10), que sugere:

I believe that the linkage between network density or closure to the utility of social capital is too narrow and partial. Research in social networks has stressed the importance of bridges in networks (Granovetter, 1973; Burt, 1992) in facilitating information and influence flows. To argue that closure or density is a requirement for social capital is to deny the significance of bridges, structural hole, or weaker ties.

Acreditamos na suposição contrária à de Lin, pois é exatamente a densidade e o fechamento dos laços dentro de um grupo que justificam, como argumentou Coleman (1990), o conceito de capital social. Os "laços fracos" são altamente significativos, mas não para fortalecer a capacidade do grupo em se articular coletivamente, mas para, nas palavras do próprio Lin, "facilitar fluxos de informação e influência". Portanto, os laços fortes e fracos referemse a fenômenos sociais distintos.

Partindo desse argumento, sugerimos que a articulação entre o conceito de capital social (laços fortes) e de redes sociais (laços fracos) possibilita um tratamento muito mais frutífero sobre a ação coletiva dos grupos carentes no ambiente urbano, do que mantendo, como sugeriu Lin, o tratamento indiferenciado entre esses fenômenos.

Mas, afinal, o que chamamos de redes sociais neste artigo? O conceito de rede social tem uma longa tradição na sociologia. ${ }^{9}$ No contexto da sociolo-

\footnotetext{
${ }^{8}$ Mais tarde, Burt (1992) propôs uma elegante teoria sobre estructural holes desenvolvendo ainda mais a distinção granovettiana.

${ }^{9}$ Excluo aqui os conceitos de redes sociais de Elias (1976) e de Castells (1999) por tratarem de "objetos" teóricos muito distintos daquele que uso neste artigo. No caso de Elias, o conceito de rede social é parte inerente de uma metateoria de sociedade centrada na ideia de interdependência
} 
gia clássica temos Simmel (1964) com a distinção entre "círculos concêntricos" de interação social ou a interação do tipo "interconexão" entre grupos. Enquanto o primeiro tipo de sociabilidade pode ser visto como o equivalente ao conceito de capital social no sentido que utilizamos aqui, o segundo equivale ao conceito de rede social que, na perspectiva do autor, reflete fenômenos sociais distintos e, também, historicamente datados. O tipo de sociabilidade "concêntrica" é mais comum nas sociedades antigas e tradicionais , já o tipo de "interconexão grupal" caracteriza a sociabilidade nas sociedades modernas.

Na sociologia contemporânea além da literatura já referida (Granovetter, Burt, Lin) é importante salientar o estudo de Blau (1987) sobre as relações macro e micro da realidade social. Embora possa parecer uma temática estranha ao tema deste artigo, não é na medida em que o seu estudo empírico utiliza o conceito de rede social para mostrar como as relações sociais em redes estruturadas demográfica e ecologicamente constituem um contexto macrossocial na determinação das decisões individuais no nível microcontextual para a escolha do(a) parceiro(a) matrimonial.

P. Blau (1987) demonstra, com boa evidência empírica, que a heterogeneidade social constitui um parâmetro estrutural, de nível macro, que produz integração matrimonial intergrupos na sociedade, independentemente dos valores culturais que poderiam prescrever exogamia ou endogamia. Embora as decisões sobre casamento sejam individuais, de nível micro, e que, obviamente, baseiam-se em normas e valores sociais para "justificar" sua escolha, o padrão estrutural das redes sociais determinam, em grande parte, as chances de prevalecer um ou outro padrão de união familiar.

Prates, Carvalhaes e Silva (2008:50-51)

Esses "achados" de Blau reforçam a ideia da teoria granovettiana distinguindo "laços fortes e fracos" nas redes sociais. Como já mencionamos, podemos olhar os laços fracos como redes sociais que estruturam demográfica e espacialmente os atores, em contraposição ao de capital social que os vincula internamente dentro dos grupos.

A hipótese central do nosso programa de pesquisa é que o grau de eficácia das comunidades carentes, no ambiente urbano, para conseguirem acesso

global e na do processo civilizador, e no caso de Castells seu objeto primordial é a utilização do conceito de redes para interpretar o processo de universalização - globalização - do mundo contemporâneo. Nenhum desses enfoques presta, a nosso ver, ao tratamento da questão empírica do papel das redes sociais na determinação das expectativas e do controle social vistos no microcontexto de ação dos atores sociais. 
a benefícios públicos depende fundamentalmente da existência de capital social associado a conexões de rede (laços fracos) da comunidade com agentes políticos ou governamentais.

\section{Teste de hipóteses}

Para testar essa hipótese desenvolvemos os dois estudos independentes já mencionados na introdução deste artigo.

\section{O estudo quantitativo}

Esse estudo já amplamente discutido em artigo anterior (Prates et al. 2008), concluiu pela plausibilidade da hipótese ao demonstrar que a eficácia coletiva, mediada por índices de qualidade de vida, é influenciada de forma significativa estatisticamente pela existência maior ou menor de capital social, mas que é a presença, ou não, de laços fracos, ou participação em redes sociais, que determina o grau de eficácia coletiva das comunidades carentes. A tabela 1 resume essa conclusão.

Tabela 1

Diferenças de médias do fator eficácia coletiva. Variável independente: capital social. Variável de controle: laços fracos

\begin{tabular}{|llrcc|}
\hline Laços fracos & Capital social & n & Média & P \\
\hline \multirow{2}{*}{ Ausência de laços } & Baixo capital social & 129 & 0,04 & \\
& Alto capital social & 143 & 0,06 & $>0,05$ \\
\multirow{2}{*}{ Presença de laços } & Baixo capital social & 16 & $-0,73$ & \\
& Alto capital social & 38 & $-0,16$ & $<0,05$ \\
\hline
\end{tabular}

Fonte: Prates et al., 2008:57.

É possível observar que há uma associação entre a existência de laços fracos e capital social no que diz respeito ao índice de eficácia coletiva, o que pode ser observado pelos valores das médias na Tabela I. Somente no grupo para o qual há essa associação as médias dos grupos de alto e baixo capital social se mostraram distintas com nível de significância estatística $(\mathrm{p}<0,05)$. Quando não há a presença dos laços fracos não há nenhuma diferença entre 
as médias do índice de eficácia para os grupos de alto e baixo capital social $(0,04$ e 0,06$)$.

Prates et al. (2008:56)

Entretanto, por se tratar de um survey, não nos foi possível contextualizar as variáveis independentes e dependentes, a não ser via criação de uma subamostra com pessoas pertencendo a um grupo de renda familiar média abaixo de três salários mínimos. Entretanto, é desnecessário demonstrar que esse procedimento é precário metodologicamente para inferirmos sobre a realidade contextual de comunidades efetivas. Para sanar essa deficiência, projetamos três estudos de caso em comunidades carentes do município de Belo Horizonte com o intuito de qualificarmos os "achados" do survey.

\section{0 estudo qualitativo}

Os três estudos de caso foram realizados em 2007 e 2008 em vilas situadas na Zona Norte da capital mineira. As vilas foram selecionadas pelas indicações dos técnicos da Regional Norte da Prefeitura de Belo Horizonte de acordo com o critério por nós estabelecido, qual seja: grau de organização interna percebida pelos técnicos da regional da prefeitura.

\section{As dimensões da análise}

Os estudos de caso buscaram identificar o volume de capital social, a capacidade de mobilização coletiva e os ganhos, em termos de benefícios públicos, da comunidade, através de entrevistas e observação etnográfica das práticas da vida cotidiana dos membros da comunidade. ${ }^{10}$

Capital social. As dimensões de capital social selecionadas para o estudo foram aquelas já utilizadas no survey, e as introduzidas nos estudos de caso:

\footnotetext{
${ }^{10}$ As entrevistas foram selecionadas a partir de indicações das lideranças formais das vilas - diretores da associação dos moradores - e daí em diante via a técnica de "bola de neve", buscando sempre balancear as entrevistas com lideranças e cidadãos comuns das vilas. Foram entrevistadas aproximadamente 13 pessoas em cada vila em um período de um ano. As entrevistas foram sempre realizadas por dois entrevistadores e foram gravadas com permissão do entrevistado. O software Nvivo8 foi utilizado para codificar e analisar os dados das entrevistas.
} 
- frequência de interação entre vizinhos - bate-papos, visitas, contatos na porta de casa;

- ajuda mútua e prestabilidade entre membros da comunidade - pequenos empréstimos de utensílios domésticos, como vasilhas de cozinha, escada, martelo etc. e de alimentos como sal, óleo de cozinha, arroz etc., tomar conta eventualmente do filho do vizinho, ajuda em pequenos consertos de casa;

- sentimento de segurança diurna e noturna - como os moradores se sentem ao transitar pela vila durante o dia e a noite, como se sentem ao frequentar os lugares coletivos como bares, mercearias, igrejas e festas, confiança nos vizinhos moradores da vila.

Além dessas que compuseram o índice de capital social do survey, foram acrescentadas:

v participação em ações coletivas da vila — reuniões da associação de moradores, orçamento participativo, mutirões para organização de festas, campanhas para conseguir algo para a vila;

v reuniões informais na casa dos moradores para discutir algum assunto.

Laços fracos: conexão em redes externas. Essa dimensão foi bastante enfatizada nos estudos de caso devido ao fato de que no questionário do survey tivemos pouca oportunidade de medi-la diretamente. Foram utilizadas apenas duas questões como proxy de laços fracos, são elas:

v participação em reuniões informais com funcionários da prefeitura para se debater algo referente à vila;

v reuniões informais entre os moradores para discutir problemas da vila.

Nos estudos de caso procuramos, então, sanar essa fragilidade do survey através do estudo de lideranças das vilas vistas como canais típicos de conexão externa. É importante lembrar aqui que nosso estudo tem como unidade de análise as comunidades e não os seus indivíduos ou moradores. Nesse caso não nos interessou, por exemplo, os laços sociais externos dos indivíduos — participação em redes - com características puramente privadas. ${ }^{11} \mathrm{O}$

\footnotetext{
${ }^{11}$ Esse dado seria, por exemplo, estratégico para um estudo centrado no conceito de capital social do Bourdieu, mas para o nosso caso cujo conceito de capital social restringe-se aos recursos
} 
conceito de liderança foi puramente indutivo, referiu-se àquelas pessoas que conectavam diferentes grupos dentro das comunidades ou que conectavam a comunidade com instituições ou grupos externos. A partir das entrevistas e observação das práticas do dia a dia dos moradores distinguimos três tipos ideais de liderança:

v a liderança institucional-formal - típica dos membros que ocupam cargos nas associações da vila;

- a liderança altruísta - típica de pessoas que buscam produzir bens coletivos independentemente dos ganhos instrumentais que daí possam advir;

v a liderança clientelista - orientada basicamente para a produção de bens coletivos que possam trazer retornos instrumentais à realização de objetivos antecipados. Normalmente esses objetivos são de natureza político-partidária ou de lealdade política.

Obviamente, encontramos esses três tipos de liderança mesclados um com o outro, a tipologia aponta apenas para a predominância de um deles nas práticas sociais.

Desorganização social. Embora essa dimensão de análise dobre, a ordem social tem sido teoricamente recorrente na literatura sociológica desde Durkheim, com o conceito de anomia, depois com o enorme e rico veio de estudos sobre delinquência e ecologia urbana da tradição da escola de Chicago (Matza, 1969; Becker, 1966) passando pelo crivo estrutural-funcional de Merton (1969) até os estudos contemporâneos quantitativos sobre organização social e criminalidade (Sampson et al., 1997), nossa intenção aqui não é rediscutir esse conceito. O termo "desorganização social" é, aqui, utilizado como referência à dimensão latente de "alienação", vista como desmotivação (seja por qualquer razão) para participar em ações comunitárias, e as dimensões descritivas de "violência" produzida por organizações criminosas externas à comunidade, como a do tráfico de drogas, e a de mobilidade espacial indicada pela mudança residencial de moradores da comunidade.

Eficácia coletiva. Essa dimensão refere-se à mesma utilizada no survey com a diferença de que, enquanto no survey as medidas eram baseadas na percepção dos respondentes sobre os equipamentos públicos existentes nos bairros, nos estudos de caso os benefícios foram inferidos diretamente pelos

gerados pelas sociabilidade informal dos membros de um grupo ou comunidade, essa informação é irrelevante. 
relatos dos moradores e observação do entrevistadores. Foram incluídos como indicadores de eficácia coletiva da comunidade qualquer produção de bens de natureza coletiva seja pela prefeitura seja pela ação coletiva interna, como por exemplo a mobilização interna para consertar uma calçada, ou uma praça, ou uma creche etc. A ideia de eficácia coletiva, no caso dos estudos de caso, é apenas comparativa, ela não tem como ser inferida de forma autônoma.

\section{Uma breve descrição das vilas à luz das dimensões teóricas}

Vila Santa Rosa. A Vila Santa Rosa situa-se na região da Pampulha, em Belo Horizonte, próxima a duas grandes vias de acesso da cidade: avenida Antonio Carlos e Anel Rodoviário. Ocupa uma área de $0,04 \mathrm{~km}^{2}$, delimitada por um perímetro de $1,01 \mathrm{~km}$ e sua densidade demográfica é de 28.125 habitantes por $\mathrm{km}^{2}$. O terreno da vila é predominantemente íngreme, os domicílios - 266 no total - são na grande maioria mal acabados e o espaço entre eles, quando há, é extremamente reduzido, de forma que a vila se configura como uma tradicional favela brasileira, evidenciando a situação de carência da sua população. Ela se encontra dividida da forma a seguir.

Tabela 2

População da Vila Santa Rosa dividida segundo faixas etárias

\begin{tabular}{|ccccc|}
\hline Até 14 anos & $\begin{array}{c}\text { Entre 15 e } 24 \\
\text { anos }\end{array}$ & $\begin{array}{c}\text { Entre 25 e 64 } \\
\text { anos }\end{array}$ & 65 anos ou mais & Total \\
\hline 393 & 257 & 436 & 39 & 1.125 \\
$(35 \%)$ & $(22,8 \%)$ & $(38,8 \%)$ & $(3,4 \%)$ & $(100 \%)$ \\
\hline
\end{tabular}

Fonte: Atlas de desenvolvimento humano da Região Metropolitana de Belo Horizonte; Fundação João Pinheiro/ Programa das Nações Unidas para o Desenvolvimento (Pnud).

A vila apresenta altos índices de mortalidade infantil: ${ }^{12} 45,6 /$ mil para crianças com até cinco anos e 41,7/mil para as de até um ano. No entanto,

\footnotetext{
${ }^{12}$ Os índices de mortalidade infantil, de educação e a renda per capita das vilas foram estimados a partir da agregação dos dados de diferentes unidades de desenvolvimento humano que apresentam índices de desenvolvimento humano (IDHs) semelhantes (Vila Santa Rosa; Favela do Aeroporto; Universitário — Vila São Miguel; Favela do Ouro Preto; Liberdade — Favela Vila Rica; e Paquetá — Vila Paquetá) de forma a se obter significância estatística.
} 
as estruturas de saneamento básico, de coleta de lixo e de energia elétrica cobrem a totalidade dos domicílios (100\%).

A tabela 3 apresenta alguns indicadores de educação da Vila Santa Rosa.

\section{Tabela 3}

Indicadores de educação da Vila Santa Rosa (2000)

\begin{tabular}{|ccc|}
\hline $\begin{array}{c}\text { Adolescentes de } 15 \text { a } 17 \text { anos } \\
\text { com menos de oito anos de } \\
\text { estudo (\%) }\end{array}$ & $\begin{array}{c}\text { Pessoas de } 18 \text { a } 24 \text { anos } \\
\text { com menos de oito anos } \\
\text { de estudo (\%) }\end{array}$ & $\begin{array}{c}\text { Escolaridade média (em } \\
\text { anos) das pessoas de } 25 \\
\text { anos ou mais }\end{array}$ \\
\hline 68,28 & 53,89 & 4,49 \\
\hline
\end{tabular}

Fonte: Atlas do desenvolvimento humano da Região Metropolitana de Belo Horizonte; Fundação João Pinheiro/ Programa das Nações Unidas para o Desenvolvimento (Pnud).

A renda per capita é de $\mathrm{R} \$ 147,77$, ao passo que a renda média dos responsáveis pelos domicílios é de $\mathrm{R} \$ 251,62$. O IDH é de 0,709. A estrutura familiar predominante na vila é a da família nuclear: pai, mãe, filhos. Há poucos casos de famílias monoparentais.
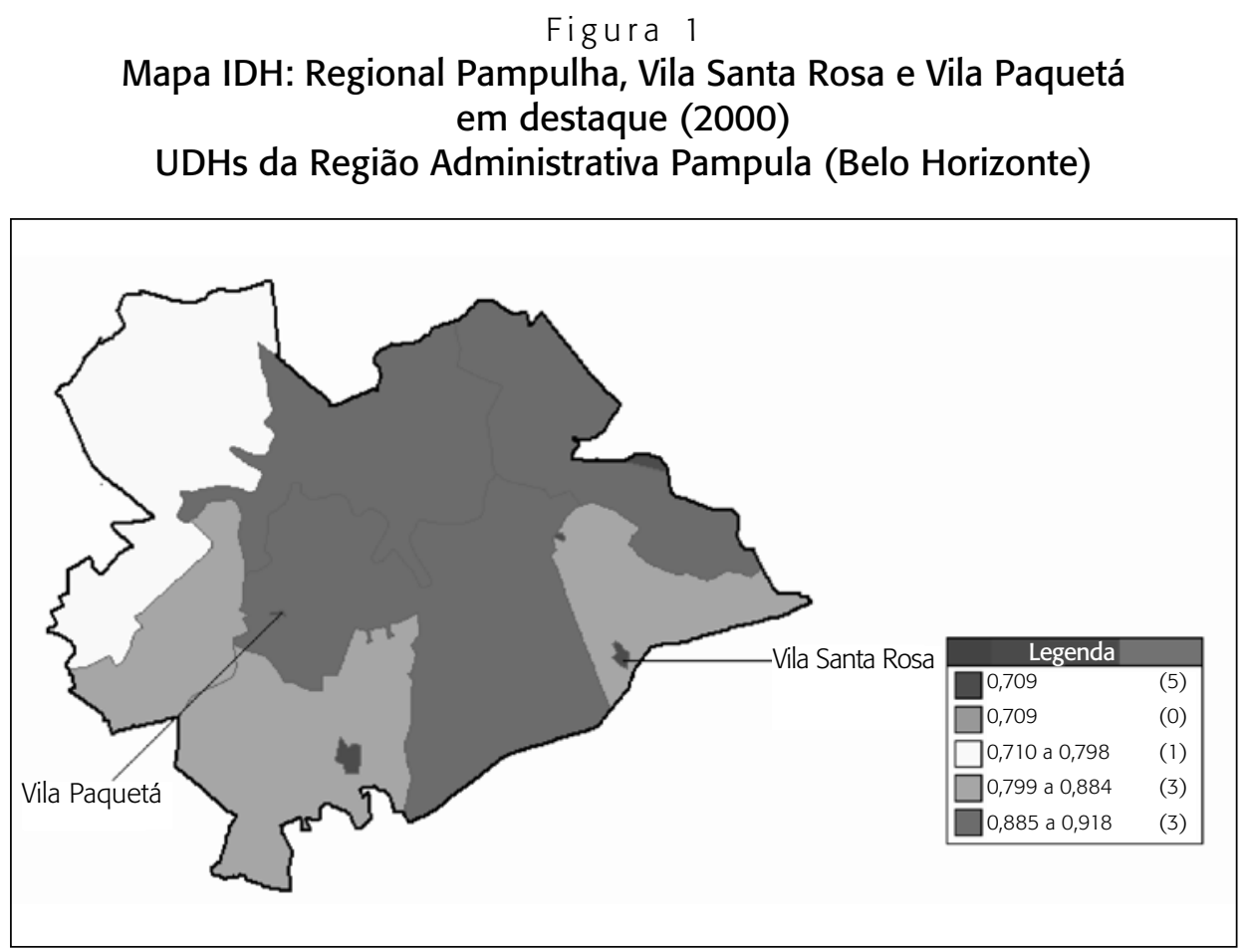
A Vila Santa Rosa é uma das mais antigas dos nossos estudos de caso. Ela foi criada na década de 1960 quando a região da Pampulha ainda era um espaço bem afastado da rede urbana da cidade. Nesse período ainda não havia infraestrutura de saneamento básico nem energia elétrica. Essa situação fez com que o "agrupamento" inicial se transformasse pouco a pouco em uma comunidade pela busca coletiva das melhorias urbanas. Naquele tempo, quase todo serviço urbano tinha grande participação dos moradores, como se expressou um dos nossos entrevistados: "a maioria das redes de esgoto que tinham no passado eram os próprios moradores que faziam essas redes de esgoto, com dificuldade, mas faziam essas redes".

Certamente, esse cenário incentivou a sociabilidade entre os moradores da vila no sentido de criação de um estoque razoável de capital social, mesmo considerando que a vila é socialmente estratificada em duas partes, a baixa e a alta, com uma visível diferença de padrão de moradia entre elas. Veja, por exemplo, algumas "falas" dos moradores que ilustram esse fato.

E: Joel, você estava falando que aqui tem muitas gerações que permaneceram na vila. Os moradores aqui são mais antigos, todo mundo conhece todo mundo, ou as pessoas se mudam daqui frequentemente?

J: Os moradores daqui são antigos. A maioria são todos antigos.

E: Você conhece bastante as pessoas?

$\mathrm{J}$ : Conheço, conheço. Inclusive ainda conheço os que eram felizes e não sabiam, aqueles que mudaram e daí dois meses voltam e dizem "Ah, se eu soubesse não tinha vendido, não tinha saído daqui".

$\mathrm{Ou}$

E: Além dessas festinhas mais dessas datas mais certas igual festa junina e tudo, o povo costuma fazer churrasco na rua, convidar os vizinhos.

Z: Faz é tipo assim, tudo que a gente faz é em prol de... tipo assim, quando a gente marca um futebol, logo depois do futebol tem a "resenha" que eles falam. Tem a queima de carne, o pessoal bebe o que tem que beber e é assim. Mas a gente convida todos sem exceção.

E: O senhor se lembra qual foi a última ocasião que você esteve com seus vizinhos em algum evento, alguma festinha?

Z: Mas a gente sempre... final de ano mesmo né. A gente sempre marca eventos pro final do ano, a gente marca evento pro Dia das Mães, pro Dia dos Pais, pro Dia das Crianças. 
E: E quem organiza esses eventos?

Z: A gente mesmo, é a gente mesmo, vaquinha, cada um contribui com o que pode contribuir. É assim que funciona.

Quanto à disposição para empréstimo ou para ajuda mútua, a seguinte "fala" expressa bem o sentimento generalizado na comunidade. Perguntado como eram os moradores quanto a essas práticas, o entrevistado respondeu:

São muito prestativas. A Vila tem muito disso, é como passa na televisão, "Oh, Fulano você tem um copinho de açúcar porque o meu acabou, olhar meu neném para mim" as pessoas são muito prestativas.

Com isso não se quer dizer que não haja uma intensa atividade mercantil dentro da vila, como prestação de pequenos serviços que vão desde tomar conta de crianças até os de bombeiro e eletricista.

Hoje, a vila é uma "ilha" como mostra o mapa do IDH, cercada de bairros de classe média onde existe um número de equipamentos públicos, escolas, hospitais, creches, e privados como comércio e prestadores de serviços. Obviamente os moradores aproveitam essa situação para se conectarem em redes sociais que trazem retornos para a comunidade. Como bem expressa a seguinte "fala" de uma liderança da comunidade:

O Vinícius Dantas ele é morador do Bairro Jaraguá. Ele é empresário da rede Tulipão de pão, de padaria e é uma pessoa que sempre tem ajudado a comunidade naquilo que pode ele está sempre ajudando. Não só na época de política, mas fora das épocas de política também é uma pessoa que sempre está com o coração aberto, sempre está ajudando. Ele também trabalhou na área social da Regional Pampulha e eu creio que ele enxerga muito bem, apesar que ele é um homem bem-sucedido financeiramente, mas ele é um homem que enxerga muito os problemas sociais.

Embora o crescimento demográfico e expansão geográfica da vila tenham se acentuado na década de 1990, percebemos que a sociabilidade não diminuiu e o sentimento de comunidade permaneceu vivo: havia referências frequentes nas entrevistas sobre a disposição para troca de favores, companheirismo e contatos informais entre vizinhos e confraternizações festivas, especialmente em fins de ano. É importante frisar que a associação de morado- 
res veio desempenhar um papel importante dentro da comunidade somente a partir da emergência do orçamento participativo (OP) em 1993. De um lado, porque esse instrumento de canalização de demandas atribuía um papel estratégico à associação de moradores, por outro, porque o OP monopolizava, cada vez mais, os recursos disponíveis para serem distribuídos para as comunidades. Assim se expressou o presidente da associação: "mas depois que entrou o OP a gente conseguiu a maioria dos benefícios, tipo o de urbanização da vila, via OP, organizando o povo. (...) Do Patrus pra cá, só as pracinhas que não foram OP, foram da prefeitura, mas aproveitou a organização pra fazer".

Esse fato não elimina, entretanto, o uso pela comunidade de canais alternativos de articulação de demandas. Tanto lideranças do tipo "clientelista" quanto as do tipo "altruísta" funcionam como "laços fracos" articulando demandas comunitárias, as "falas" seguintes ilustram esses dois tipos de conexões. Perguntados como a comunidade conseguia benefícios para a vila, assim se expressaram:

eu fiquei um ano lutando para conseguir desentupir essa boca de lobo e agora na semana passada eles vieram e desentupiram para gente. Mas, é bem fácil se a pessoa ficar em cima, se tiver uma obra pequena daquele porte ali, e ficar ligando para a regional, aguardar o número de protocolo, do pedido... Eu posso te falar que uma coisa que me ajuda muito nisso é o fato do gabinete, porque quando eles começam a me enrolar um pouco eu peço o gabinete para mandar o ofício diretamente e aí acaba que eles sentem um pouco mais de pressão e fazem a obra com mais urgência (moradora, liderança altruísta).

olha vocês não participam, vocês não correm atrás, vocês só sabem falar o vereador só vem aqui no dia de voto, mais se todo mundo votou nele todo mundo tem que ir é atrás dele mais ninguém não faz isso. Então que nem esse Vinícius o grande prazer dele aqui é de falar que ele fez uma creche que eu fiquei sabendo que saiu até no jornalzinho, mas só que não fez creche nenhuma aqui e aí ele veio aqui pra pedir voto aí teve gente que falou assim: ah eu vou porque eu quero conseguir um bom emprego pra mim e pra minha esposa (fala de moradora referindo-se às lideranças clientelistas).

A primeira entrevista ilustra uma liderança institucional, a segunda, uma altruísta, e a terceira faz referência aos canais clientelistas. No caso dessa vila, o uso alternativo dos três tipos de canais, liderança institucional, altruísta e clientelista, possibilitou um grau expressivo de eficácia coletiva (ver tabela 8 a seguir). 
Esse cenário de uma vida cotidiana pacata, calma e ordeira, permaneceu até o ano 2000. Em 2001 as organizações do tráfico de drogas começam a atuar na vila, recrutando adolescentes como consumidores e alguns como seus membros. A violência expressa por brigas de jovens, ameaças, degradações do ambiente urbano, barulhos na madrugada, vandalismo nos equipamentos urbanos, como praças e em muros de residências, produziu um forte sentimento de insegurança entre os moradores. Vale ressaltar que a atuação do tráfico não atingiu, no interior da vila, o ponto de conflitos armados tal como ocorre na maioria dos aglomerados urbanos das grandes cidades brasileiras, mas gerou sentimento de medo e de ameaça entre os moradores, tornando-os reticentes para agir ou mesmo para exercer seu direito de ir e vir livremente na vizinhança. As "falas" a seguir ilustram esse tipo de sentimento. As duas primeiras pertencem a lideranças comunitárias, a terceira a um morador comum da vila:

está faltando as juninas, que eram as que tinham danças e esse tipo de coisa e está meio difícil, por causa do financeiro e até porque as pessoas estão um pouco assustadas com a violência que cresceu um pouco aqui.

Então por causa disso [violência] o pessoal foi se afastando. A gente já não faz mais barraquinha igual a gente fazia antes. Aí o povo já se entrosava mais, já convivia mais. $\mathrm{O}$ povo já não fica naquela tranquilidade na rua.

Ah, minha filha, você podia dormir de portas abertas, hoje em dia você não pode esquecer nada.

Claramente, o tráfico de drogas, um fator externo à comunidade, desencadeou um processo de medo e percepção de aumento da violência no interior da vila, levando, muitas vezes, a um comportamento "alienante" no que diz respeito ao envolvimento informal dos moradores nas práticas coletivas. É importante salientar que esse processo de "desorganização social" interna não se deveu a fatores endógenos à comunidade, como "desestruturação familiar", desemprego e anomia no sentido de algumas teorias clássicas de desorganização social, mas sim de um fator claramente exógeno à comunidade: a organização criminosa do tráfico.

Vila São Tomás. A Vila São Tomás situa-se na região norte de Belo Horizonte, ao lado do Aeroporto da Pampulha. Ocupa uma área de $0,48 \mathrm{~km}^{2}$ delimitada por um perímetro de $3,9 \mathrm{~km}$ e a densidade demográfica é de $16.487,5$ habitantes por $\mathrm{km}^{2}$. Possui um total de 2.081 domicílios e, diferentemente das vilas Santa Rosa e Paquetá, há áreas levemente mais urbanizadas, com algu- 
mas vias de acesso pavimentadas. Ainda é, no entanto, uma região vulnerável e empobrecida.

Tabela 4

População da Vila São Tomás dividida segundo faixas etárias (2000)

\begin{tabular}{|ccccc|}
\hline Até 14 anos & $\begin{array}{c}\text { Entre 15 e 24 } \\
\text { anos }\end{array}$ & $\begin{array}{c}\text { Entre 25 e 64 } \\
\text { anos }\end{array}$ & $\begin{array}{c}65 \text { anos ou } \\
\text { mais }\end{array}$ & Total \\
\hline 2.398 & 1.722 & 3.476 & 348 & 7.914 \\
$(30,3 \%)$ & $(21,76 \%)$ & $(44 \%)$ & $(3,94 \%)$ & $(100 \%)$ \\
\hline
\end{tabular}

Fonte: Atlas do desenvolvimento humano da Região Metropolitana de Belo Horizonte; Fundação João Pinheiro/ Pnud.

Os índices de mortalidade infantil ${ }^{13}$ são de $43,55 / \mathrm{mil}$ para as crianças com até um ano e de 47,6/mil para as de até cinco anos. O percentual de domićlios com água encanada é de $92,3 \%$; 95,90\% possuem serviço de coleta de lixo; e 99,8\% possuem energia elétrica. A tabela 5 apresenta alguns indicadores de educação da vila.

Tabela 5

Indicadores de educação da Vila São Tomás (2000)

\begin{tabular}{|ccc|}
\hline $\begin{array}{c}\text { Adolescentes de } 15 \text { a } 17 \text { anos } \\
\text { com menos de oito anos de } \\
\text { estudo (\%) }\end{array}$ & $\begin{array}{c}\text { Pessoas de } 18 \text { a } 24 \text { anos } \\
\text { com menos de oito anos de } \\
\text { estudo (\%) }\end{array}$ & $\begin{array}{c}\text { Escolaridade média das } \\
\text { pessoas de } 25 \text { anos ou } \\
\text { mais }\end{array}$ \\
\hline 70,84 & 53,80 & 4,86 \\
\hline
\end{tabular}

Fonte: Atlas do desenvolvimento humano da Região Metropolitana de Belo Horizonte; Fundação João Pinheiro/ Pnud.

A renda per capita é de $\mathrm{R} \$ 160,87$ e o rendimento médio dos responsáveis pelo domicílio é de $\mathrm{R} \$ 412,89$. O IDH é levemente superior ao das vilas Santa Rosa e Paquetá, 0,716, sendo também considerada pelo Pnud como médio desenvolvimento humano (IDH entre 0,5 e 0,8). Comparando com as

\footnotetext{
${ }^{13}$ O procedimento para os indicadores da Vila São Tomás foi o mesmo utilizado para as vilas Santa Rosa e Paquetá. No entanto, por situar-se em região distinta da Região Metropolitana de Belo Horizonte (RMBH), os dados da Vila São Tomás foram agregados aos de outras unidades de desenvolvimento humano com IDHs semelhantes (Vila São Tomás; Heliópolis — Vila Aeroporto; Chácaras Reunidas Santa Inês; e Tupi — Vila Ribeiro de Abreu).
} 
outras unidades de desenvolvimento humano da RMBH, a Vila São Tomás ocupa a 109a posição, com 108 UDHs em situação melhor (67,5\%) e 51 UDHs $(31,9 \%)$ em situação pior ou igual. A estrutura familiar é predominantemente monoparental feminina com filhos de pais diferentes.

\section{Figura 2}

Mapa IDH: Regional Norte, Vila São Tomás em destaque (2000) UDHs da Região Administrativa Norte (Belo Horizonte)

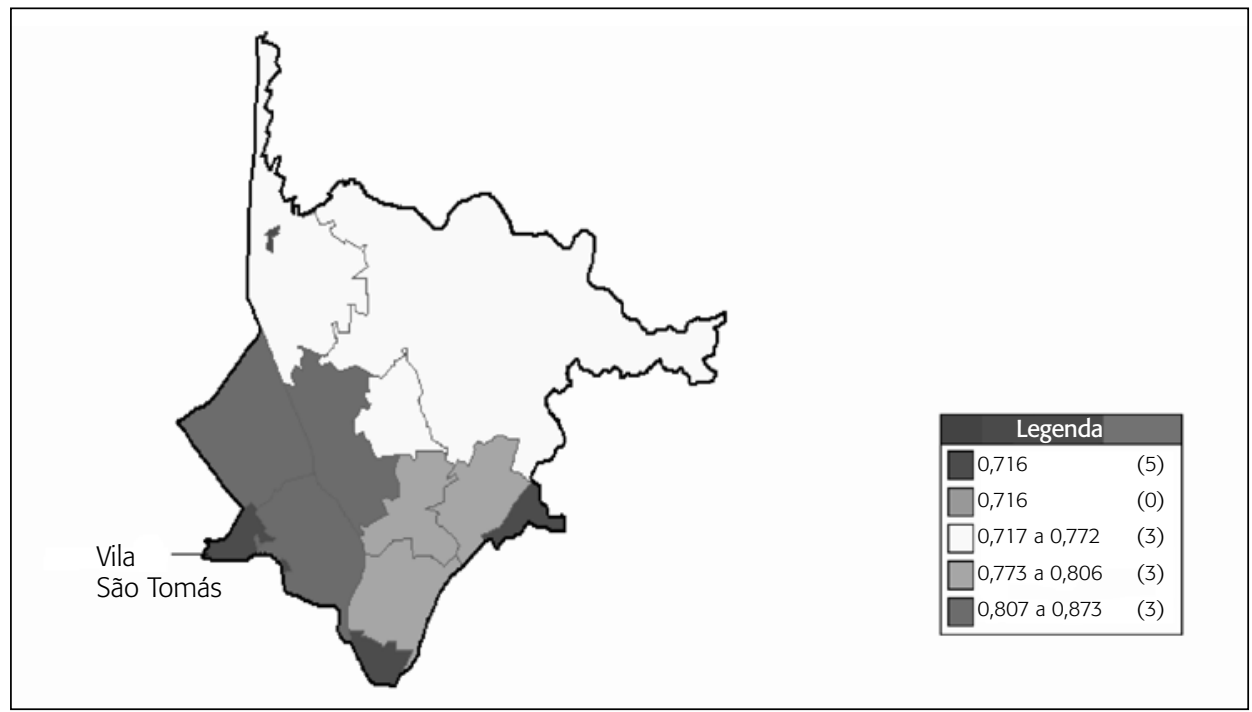

Como se pode constatar, assim como a Vila Santa Rosa, esta comunidade é uma pequena ilha cercada por bairros de classe média onde se encontra todo tipo de equipamento urbano. Mas diferentemente das outras duas vilas, a Vila São Tomás é mais urbanizada em termos de vias de acesso - ruas pavimentadas - e em algumas áreas as residências apresentam um padrão de construção bem acima daqueles comumente encontrados em vilas e favelas urbanas das grandes cidades brasileiras. A vila é, também, bastante antiga, surgiu em meados dos anos 1960 quando, então, não havia qualquer acesso à infraestrutura de saneamento como água e energia elétrica. Nesse período essa região da Pampulha era pouco habitada, com precária urbanização e pouca atividade comercial. Como a Santa Rosa, a Vila São Tomás tem um sistema de estratificação espacial e social dentro dela. A parte superior da vila — próximo a uma grande e importante via urbana de um bairro de classe média, o Itapoã - é bastante urbanizada com ruas largas, asfaltadas, residências de 
porte médio bem construídas, quase se integra com o bairro vizinho de classe média. Já a parte baixa da vila, próxima ao Aeroporto da Pampulha, tem todas as características típicas das favelas urbanas: urbanização irregular, domicílios sem lotes ou acabamentos definidos, e muitos becos usados como vias de circulação. Aqui, também, esse padrão de estratificação, embora seja claramente visível, não chega a produzir uma segmentação de identidade que comprometa o sentimento de unidade da vila. Há intensa rede de relações mercantis de prestação de serviços, o que não impede a presença de alto estoque de capital social (ver tabela 8 a seguir), com uma rica rede de laços informais que sedimentam a coesão da comunidade. As "falas" a seguir de lideranças e moradores da vila ilustram essa dimensão:

mora todo mundo aqui perto sim, todo mundo a gente conhece, se precisar chamar a qualquer hora ou ligar eles sempre estão prontos pra nos atender.

a gente sempre se encontra, se eu passo eu brinco com todo mundo, grito um depois grito o outro. Tem as crianças que vêm todas e me abraçam, pedem benção, elas me têm como vovó delas. É tudo mundo como se fosse da família (entrevista de uma liderança informal).

eu acho que São Tomás é uma festa, as pessoas falam que parece mais uma cidade de interior do que bairro da capital, porque passa cavalo passa cabrito passa porco aí você passa na rua e tem sempre alguém sentado na porta da rua batendo papo com alguém e é muito legal. Eu acho que agora está meio difícil porque as pessoas estão trabalhando muito, mas geralmente a gente vê no final da tarde o povo juntam-se e vão colocar a conversa em dia ou junta ali no boteco, boteco é uma coisa que tem no São Tomás meu amigo! Eu falei que é que deve seu do bairro dos botecos, já reparou! A que nomear rua nas temos o Miguel, dona Sia, 2, tem o IG, 3, pica pau, 4, peixe 5, em dois quarteirões têm de cinco bares, um do lado do outro. É uma coisa que eu acho interessante que racho de rir que o dono do boteco de lá vem beber cerveja com o dono do boteco daqui, e o cara do boteco daqui senta ali para tomar cerveja ali sacou! Então é muito divertido você não acredita, o cara vende cerveja e fica sentado no boteco do outro tomando cerveja, então eu acho que aqui parece muito com cidade do interior (moradora comum).

No geral né? Porque aqui é um local muito bom de morar e tem muita gente que já mudou daqui e arrependeu e tá querendo voltar, e não tem como voltar. Você entendeu? Então quer dizer, não é uma comunidade ruim né? Se o pessoal tá querendo retornar porque não é uma comunidade ruim (morador comum). 
De outro lado, a vila é rica em conexões externas formando redes eficientes de produção de bens coletivos. Várias ONGs e associações estão presentes na vila com programas sociais, a Associação Brasileira Comunitária para a Prevenção do Abuso de Drogas (Abraço), Legião Brasileira da Boa Vontade (LBV), Educação de Jovens Adultos (EGV), vários grupos religiosos etc. A presença dessas instituições conectando a vila com o mundo exterior é fruto do exercício de lideranças formais e informais dos tipos "altruísta", "institucional" e "clientelista". Abaixo temos "falas" que caracterizam estes tipos distintos de lideranças:

Tudo eles vêm na associação pedir. (...) Trazem demandas e a gente encaminha para a regional, pra Cemig, pra Copasa (liderança institucional, presidente da Associação de Moradores da Vila São Tomás).

Eu faço um trabalho do bairro, das ruas, arrumar as ruas, tampar os buracos... eu peço e eles vêm... outra coisa é a limpeza do córrego. (...) Eu faço contato com a prefeitura, com a Urbel, com o tampa buraco... (liderança altruísta, moradora da Vila São Tomás).

Qual é o benefício que eles tiveram lá embaixo, era os becos que era tudo, coisa difícil, e nós conseguimos pra eles, ao menos asfaltar os becos de rua pra eles (liderança altruísta, moradora da Vila São Tomás).

Vila Paquetá. A Vila Paquetá também se situa na região da Pampulha em Belo Horizonte, estando, no entanto, distante de qualquer grande via de acesso da cidade. Sua área formada por apenas um único quarteirão é de $0,01 \mathrm{~km}^{2}$ e é delimitada por um perímetro de $0,66 \mathrm{~km}$. Diferentemente da Vila Santa Rosa, o terreno é na sua totalidade plano. As casas também são mal acabadas e há pouco ou nenhum espaço entre elas. A população se divide da forma a seguir.

Tabela 6

População da Vila Paquetá dividida segundo faixas etárias (2000)

\begin{tabular}{|ccccc|}
\hline Até 14 anos & $\begin{array}{c}\text { Entre } 15 \text { e } 24 \\
\text { anos }\end{array}$ & $\begin{array}{c}\text { Entre } 25 \text { e } 64 \\
\text { anos }\end{array}$ & 65 anos ou mais & Total \\
\hline 219 & 188 & 275 & 16 & 698 \\
$(31,3 \%)$ & $(27 \%)$ & $(39,4 \%)$ & $(2,3 \%)$ & $(100 \%)$ \\
\hline
\end{tabular}

Fonte: Atlas do desenvolvimento humano da Região Metropolitana de Belo Horizonte; Fundação João Pinheiro/ Pnud. 
Os índices de mortalidade ${ }^{14}$ infantil são os mesmos de Vila Santa Rosa: 45,6/mil para crianças com até cinco anos e 41,7/mil para as de até um ano. O mesmo se refere às estruturas de saneamento básico, coleta de lixo e energia elétrica: cobertura de $100 \%$ dos domicílios.

A tabela 7 apresenta alguns indicadores de educação da Vila Paquetá.

Tabela 7

Indicadores de educação da Vila Paquetá (2000)

\begin{tabular}{|ccc|}
\hline $\begin{array}{c}\text { Adolescentes de 15 a } 17 \\
\text { anos com menos de oito } \\
\text { anos de estudo (\%) }\end{array}$ & $\begin{array}{c}\text { Pessoas de 18 a 24 anos } \\
\text { com menos de oito anos } \\
\text { de estudo (\%) }\end{array}$ & $\begin{array}{c}\text { Escolaridade média das } \\
\text { pessoas de 25 anos ou } \\
\text { mais }\end{array}$ \\
\hline 68,28 & 53,89 & 4,49 \\
\hline
\end{tabular}

Fonte: Atlas do desenvolvimento humano da Região Metropolitana de Belo Horizonte; Fundação João Pinheiro/Pnud.

A renda per capita da Vila Paquetá também é de $\mathrm{R} \$ 147,77$, enquanto o rendimento médio dos responsáveis pelo domicílio é de $\mathrm{R} \$ 249,08$. O IDH, tal como o da Vila Santa Rosa é de 0,709, considerado pelo Pnud como médio índice de desenvolvimento humano (IDH entre 0,5 e 0,8 ). Ao se comparar com as outras unidades de desenvolvimento humano da RMBH, no entanto, as vilas Paquetá e Santa Rosa ocupam a $122^{\mathrm{a}}$ posição, sendo que 121 UDHs $(75,6 \%)$ se encontram em situação melhor e 37 UDHs $(23,1 \%)$ em situação igual ou pior.

A estrutura familiar predominante é a nuclear: pai, mãe e filhos. Essa é a menor das três vilas dos nossos estudos de caso e também a menos eficaz em termos de lograr êxito na busca de benefícios coletivos (ver tabela 8). Embora disponha de um razoável estoque de capital social, é visível a inexistência de laços conectando a comunidade com o exterior. As referências a seguir ilustram a presença de capital social na forma de sentimento de família, no tocante à comunidade, ajuda mútua e prestabilidade.

as pessoas aqui são muito gente boa e todos prestativos. Se chegar a acontecer alguma coisa todos estão pra ajudar, aqui nós somos como uma família aqui na

\footnotetext{
${ }^{14}$ Como já mencionado, o cálculo dos indicadores de mortalidade, educação e renda per capita foram estimados a partir da agregação dos dados de diferentes unidades de desenvolvimento humano que apresentam IDHs semelhantes (Vila Santa Rosa; Favela do Aeroporto; Universitário - Vila São Miguel; Favela do Ouro Preto; Liberdade — Favela Vila Rica; e Paquetá — Vila Paquetá) de forma a se obter significância estatística.
} 
vila. Tinha o pastor Malta pra ajudar que todo mundo conhece, desse problema eu não tenho nada assim pra reclamar não (moradora da vila).

A gente se uniu ali porque realmente a vila é muito pequenininha e a gente realmente é uma família mesmo e apesar da vila ter o seu lado de violência de ter alguns atritos, mais o pessoal lá é muito humano e principalmente aquele pessoal mais antigo sempre que precisa de ajuda eles sempre estão ajudando e dificilmente recebe um não na porta porque são pessoas muito solidárias e que ajudam mesmo e gostam de ajuda (moradora da vila).

Esse forte sentimento comunitário é a base de uma grande coesão interna que, entretanto, não se traduz em eficácia coletiva (ver tabela 8). A razão disso pode estar na quase ausência de "laços fracos", lideranças, conectando a comunidade com os provedores de serviços públicos.

E: Por que você acha que a vila não consegue certos tipos de benefícios?

(...) aí é por que ela não tem um líder, ela não tem uma comunidade na verdade porque se tivesse uma associação na verdade. Na comunidade tem que ter uma associação se ela tiver, com certeza isso aí sim é 100\% garantido, se ela tiver um representante uma pessoa que tem coragem de lutar e correr atrás e procurar outros caminhos, que tem outros caminhos (moradora da vila).

A associação dos moradores está desativada e não se consegue mobilizar a comunidade para reativá-la, "não tem um representante, um líder mesmo, porque sem o líder não adianta, não se consegue nada mesmo" (moradora da vila).

Quanto ao nível de "desorganização social” a Vila Paquetá tem pouco a se queixar. Por ser bastante pequena espacial e demograficamente, a vila não parece constituir um alvo para as organizações criminosas do tráfico. As pessoas gostam de morar nela e não sentem a insegurança que marcou alguns períodos da trajetória de vida das outras comunidades ameaçadas pelas organizações do tráfico de drogas.

\section{Análise de dados: construção dos modelos interpretativos}

Tomando como referência essas quatro dimensões, apresentamos a seguir a posição relativa de cada vila em relação a elas. 
Tabela 8

Indicadores das dimensões teóricas (\%)

\begin{tabular}{|lcccc|}
\hline Indicador & Vila São Tomás & Vila Santa Rosa & Vila Paquetá & Total \\
\hline Eficácia coletiva & 43,21 & 35,80 & 20,99 & 100 \\
Laços fracos & 41,98 & 50,62 & 7,41 & 100 \\
Capital social & 38,31 & 29,03 & 32,66 & 100 \\
Desorganização social & 25,00 & 45,12 & 29,88 & 100 \\
\hline
\end{tabular}

Fonte: Dados primários da pesquisa.

A hipótese principal e inicial do nosso estudo pode ser ilustrada pela figura 3.

Modelo da hipótese principal e inicial do estudo

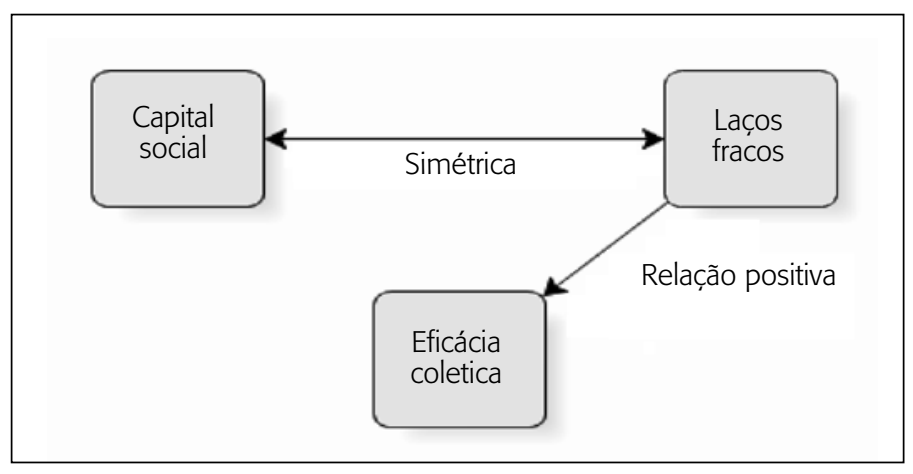

A variável dependente "eficácia coletiva" estaria relacionada positivamente a laços fracos - conexões exteriores - e estes, por sua vez, se relacionariam positivamente a capital social. Foi essa hipótese que nos guiou no trabalho de campo.

Quando comparamos as três vilas nas dimensões "laços fracos", "capital social" e "eficácia coletiva" na tabela 8, podemos ver que há correspondência entre o volume de referências nessas dimensões no sentido da nossa hipótese. Embora encontremos mais referências a laços fracos na Vila Santa Rosa relativamente à Vila São Tomás que, por sua vez, apresenta mais referências a benefícios coletivos (eficácia coletiva), pode-se ver, ao mesmo tempo, que quando se trata de capital social, a Vila São Tomás prevalece sobre a Santa Rosa. Isso indica que na São Tomás há maior chance de ocorrência de ação 
coletiva, facilitando, assim, a produção de benefícios coletivos via mobilização interna. No caso da Vila Paquetá, o volume e sentido das referências comparadas com as outras vilas, corroboram plenamente nossa hipótese.

Ao olharmos a natureza dos laços fracos nas entrevistas das três comunidades constatamos que o comportamento que articula sociedade civil-Estado não difere do padrão dominante da sociedade brasileira. Os laços fracos predominantes são aqueles de caráter clientelista, seguidos dos de caráter altruísta com certo carisma associado a ele, ambos de natureza informal, e, finalmente, os de caráter institucional-formal, mais frágeis e menos frequentes. A partir dessa constatação agregamos essas variáveis no nosso modelo inicial que se configurou na figura 4.

Figura 4

Modelo agregando novas variáveis

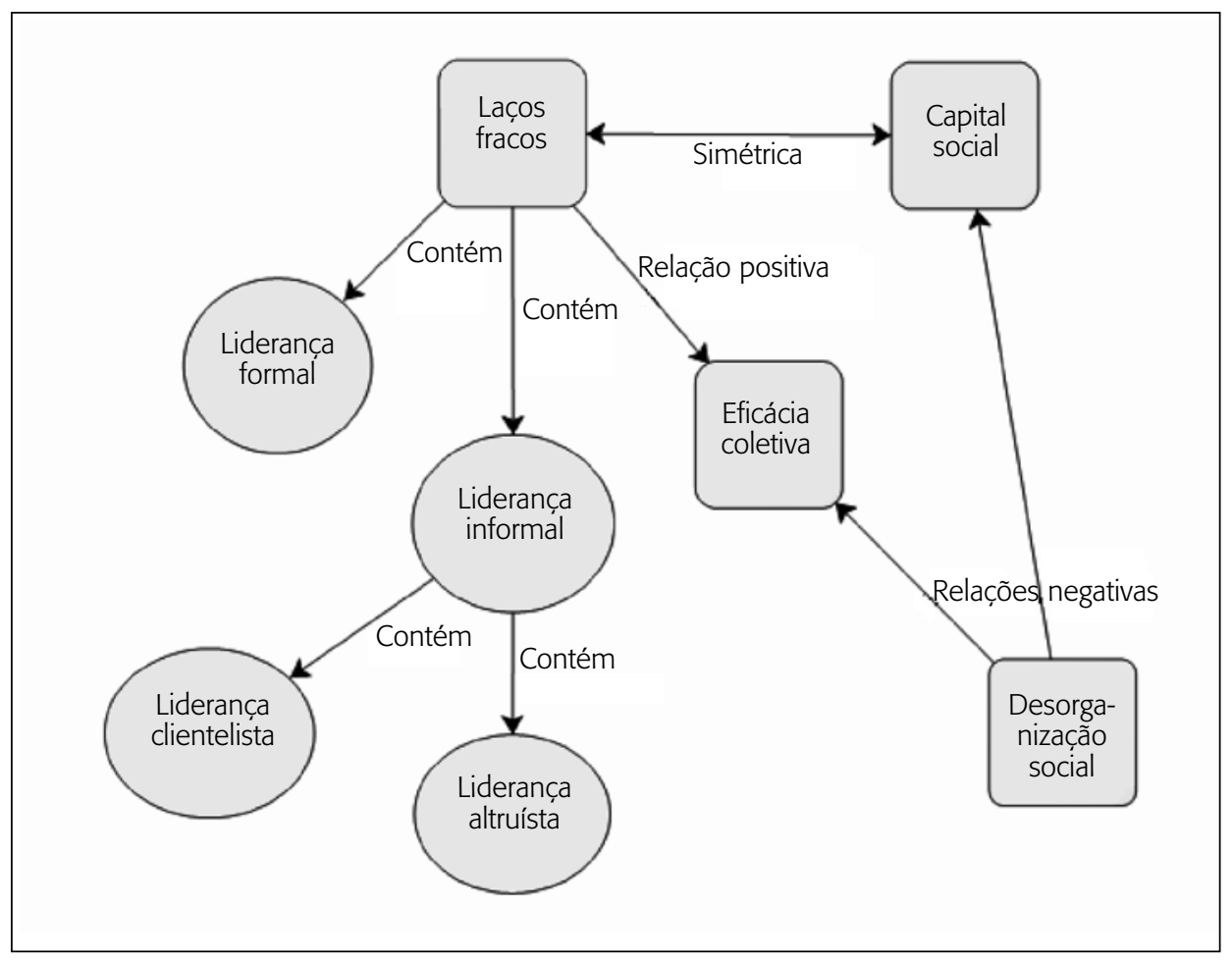

Focalizando, agora, a existência de capital social, contatamos a inegável força dessa dimensão para a sustentação do sentimento de ordem e solidarie- 
dade dentro das comunidades e, como salientamos acima, esse fator diminui os custos da ação coletiva facilitando, assim, a mobilização interna.

Além das práticas paternalistas das lideranças altruístas e clientelistas que produzem bens coletivos, sem qualquer exigência de investimento em participação dos beneficiários, o que, obviamente, favorece a "lógica do carona", há, também, fatores exógenos que penetram o contexto social da comunidade aumentando enormemente o custo da participação. Esses fatores constituem a dimensão de "desorganização social" na comunidade, entre eles o mais importante é a violência produzida pelo tráfico de drogas.

A análise comparativa dessa dimensão nas três comunidades (tabela 8) mostra claramente esse fato: a Vila Santa Rosa é, de longe, a que mais demonstra sentimento de insegurança relacionado à ameaça do tráfico de drogas. Das 75 referências especificamente sobre violência nas três comunidades, $47 \%$ foram relatadas pela Vila Santa Rosa. Como se poderia esperar, é também essa vila a que menos apresenta indicadores de capital social. Esse fato levou-nos a remodelar a figura 4 agregando a dimensão de desorganização social que se tornou a figura 5 .

Figura 5

Modelo agregando a dimensão de desorganização social

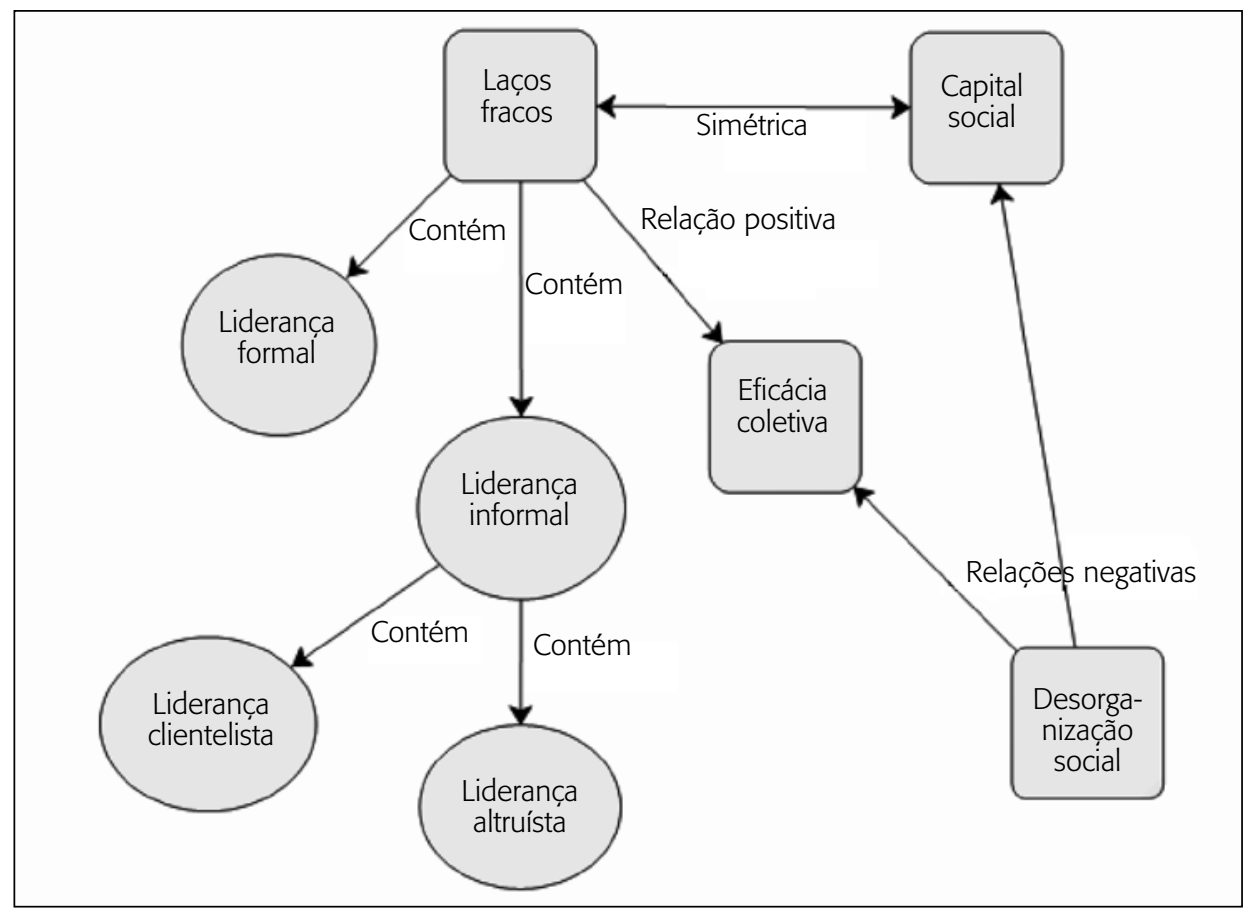




\section{Conclusão}

A conclusão final do nosso estudo está bem ilustrada pela figura 6 .

Figura 6

\section{Modelo final}

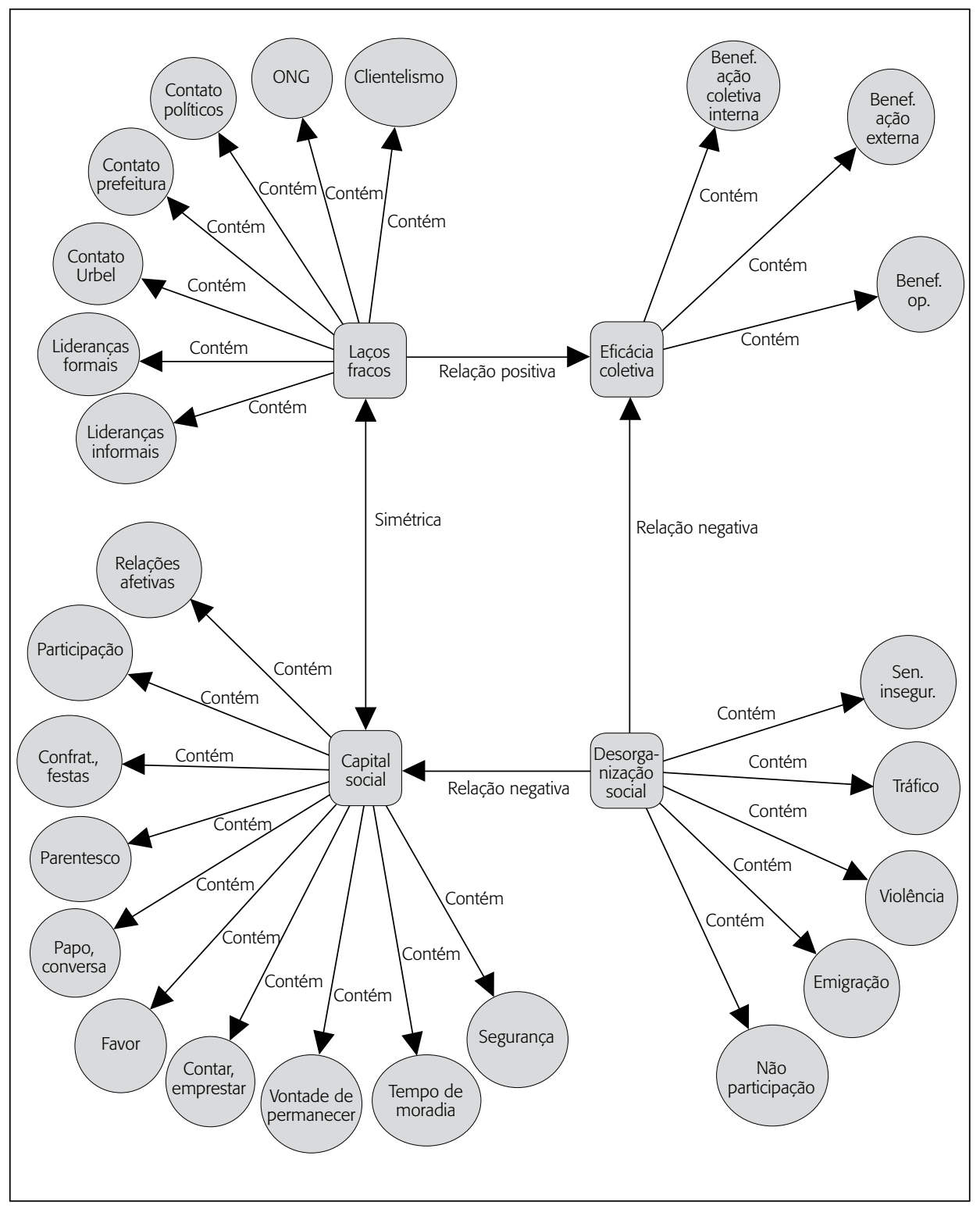


Os "quadrados" são as dimensões teóricas do modelo e as formas circulares mostram os referentes empíricos, indicadores, identificados pelas entrevistas, de cada dimensão teórica. A seguir, as conclusões principais do estudo.

\section{Laços fracos}

Os laços fracos são de fundamental importância para que a comunidade tenha alguma eficácia coletiva para conseguir bens públicos. Eles podem ser de três tipos:

v altruísta - é o tipo de liderança espontânea voltada para a realização de benefícios coletivos. Esse tipo de liderança é informal e funciona como um mediador entre as demandas dos membros da comunidade e os agentes públicos ou políticos capazes de prover esses bens;

v clientelista - é um tipo de liderança voltado para beneficiar a comunidade ou parte dos seus membros por meio de conexões particulares com políticos ou funcionários do poder público;

v institucional-formal - esse tipo refere-se especificamente às lideranças formais membros da diretoria da associação comunitária. Como seria de se esperar, a função precípua desse tipo de liderança é justamente articular as demandas da comunidade e levá-las às agências públicas provedoras de bens públicos.

\section{Capital social}

Constitui um recurso estratégico de ação coletiva voltada para a produção de bens coletivos internos, tais como ajuda mútua, participação em construção ou conserto de barracos, prestatividade e participação no orçamento participativo (OP). Contudo, foi constatado pelo nosso estudo que esse fator, por si só, facilita a ação coletiva, mas não é o mais crítico na determinação da eficácia coletiva da comunidade, a não ser no caso do OP que constitui um canal formal e induzido de participação. ${ }^{15}$

\footnotetext{
${ }^{15}$ Para a discussão de uma tipologia de participação em programas sociais, ver Prates et al. (1982).
} 
As três variáveis básicas da nossa hipótese principal — laços fracos, capital social e eficácia coletiva - estão relacionadas com o "grau de desorganização social" da comunidade, indicada pela "violência" (especialmente a produzida externamente pelo tráfico de drogas) e o grau de "alienação" dos membros da comunidade diante do interesse em participar para a produção de bens coletivos. Essas duas variáveis se relacionam negativamente com capital social que, por seu turno, afetam indiretamente a capacidade de produção de bens coletivos internos.

\section{Referências}

ARROW, R. J. Observation on social capital. In: DAGUSPTA, P.; IERAGELDIN, I. (Eds.). Social capital: a multifaceted perspective. Washington: The World Bank, 1999. p. 3-5.

BECKER, S. H. Outsiders. New York: The Free Press, 1966.

BOURDIEU, P. The forms of social capital. In: RICHARDSON, J. G. (Ed.). Handbook of theory and research for the sociology of education. New York: Greenwood, 1986.

BURT, R. Structural holes: the social structure of competition. Massachusetts: Harvard University Press, 1992.

. Structural holes versus network closure as social capital. In: LIN, N.; COOK, K.; BURT, R. (Eds.). Social capital theory and research. New York: Aldine de Gruyter, 2000.

CASTELLS, M. A sociedade em rede (a era da informação: economia, sociedade e cultura). 2. ed. São Paulo: Paz e Terra, 1999. v. 1.

COLEMAN, J. Foundations of social theory. Cambridge, Mass.: Belknap Press, 1990.

ELIAS, N. O processo civilizador. Rio de Janeiro: Jorge Zahar, 1994.

FUKUYAMA, F. Social capital, civil society and development. Third World Quarterly, v. 22, 2001.

GRANOVETTER, M. The strength of weak ties. American Journal of Sociology, n. 78, p. 1360-1380, 1973.

LIN, N. Building a network theory of social capital. In: LIN, N.; COOK, K.; BURT, R. (Eds.). Social capital theory and research. New York: Aldine de Gruyter, 2000. 
MATZA, D. Becoming deviant. New Jersey: Englewood Cliffs, 1969.

MERTON, R. K. Social theory and social structure. Illinois: Glencoe, 1949.

OLSON, M. The logic of collective action: public goods and the theory of groups. Cambridge, MA: Harvard University Press, 1965.

PORTES, A. Social capital: its origins and application in modern sociology. Annual Review of Sociology, v. 24, n. 1, p. 1-23, 1998.

PRATES, A. A. P. Making democracy work. Civic traditions in modern Italy. Resenha. Teoria \& Sociedade, n. 1, p. 193-201, 1997.

et al. Emergência do planejamento participativo em Minas Gerais: um balanço político-institucional. Análise e Conjuntura, Belo Horizonte, v. 12, 1982.

; CARVALHAES, A. O.; SILVA, B. F. A. Capital social e redes sociais: conceitos redundantes ou complementares? In: AGUIAR, N. (Org.). Desigualdades sociais, redes de sociabilidade e participação política. Belo Horizonte: UFMG, 2008.

PUTNAM, R. D. Comunidade e democracia: a experiência da Itália moderna. Rio de Janeiro: FGV, 1996.

ROBINSON, L. J. et al. Is social capital really capital? Washington: World Bank, 2002 .

SACHS, I.; LAGES, V. N. Capital social y desenvolvimiento: novedad para quem? In: CONFERÊNCIA REGIONAL SOBRE CAPITAL SOCIAL Y POBREZA. 2001. Anales... Santiago, Chile: Cepal/University of Michigan, 2001.

SAMPSON, R. J. et al. Neighborhoods and violent crime: a multilevel study of collective efficacy. Science, v. 277, n. 5.328, p. 918-924, 1997.

VERBA, S.; ALMOND, G. The civic culture: political attitudes and democracy in five countries. New Jersey: Princeton University Press, 1963.

WOOLCOCK, M. Social capital and economic development: toward a theoretical synthesis and policy framework? Theory and Society, v. 27, n. 2, 1998. 